\title{
Can Agritourism be a Viable Niche Market for the Small Romanian Fruits and Vegetables Producers?
}

\author{
Cătălin-Răzvan V. VÎNTU ${ }^{1}$, Aurel C. CHIRAN², \\ Elena C. LEONTE², Marcela ȘTEFAN³, Mugurel I. JITEA ${ }^{4 *}$ \\ ${ }^{1}$ University of Agronomic Sciences and Veterinary Medicine of Bucharest, 59 Mărăşti Boulevard, District 1, 011464 Bucharest, \\ Romania; catalin_vintu@yahoo.com \\ 2"Ion Ionescu de la Brad" University of Agricultural Sciences and Veterinary Medicine Iaşi, 3 M. Sadoveanu Alley, 700490 Iaşi, Romania \\ ${ }^{3}$ Academy of Economic Studies, Faculty of Agrifood and Environmental Economics, 5-7 Mihail Moxa St., District 1, 010961, Bucharest, \\ Romania; stefanmarcela57@yahoo.com \\ ${ }^{4}$ University of Agricultural Sciences and Veterinary Medicine, 3-5 Manastur St., 400372, Cluj-Napoca, \\ Romania; mjitea@usamvcluj.ro ( ${ }^{*}$ correspondingauthor)
}

\begin{abstract}
The paper investigates the main changes that have taken place in the Romanian fruits and vegetables supply chain over the past twenty years. Its sustainability is assessed using time-series data from different official and private data-bases applying statistic research methods. Results showed that the Romanian supply chain is dominated in terms of both inputs used and offer, by imports originating from different EU countries. The local subsistence and semi-subsistence farms cannot provide enough qualitative and quantitative products such as to penetrate the supermarkets, the main players from the market. Agritourism, a potential niche market, was investigated using sampling techniques. The guesthouses from one of the most important ecotourism destinations where assessed by face-to-face interviews. Results showed that even such short-marketing chains are unsustainable tools for the fresh fruits and vegetables products sectors. The lack of governance for the local producers does not allow them to enter on such niche market. All this findings can provide important incentives for better future targeted sectorial agricultural policies.
\end{abstract}

Keywords: short supply chain, sustainability, local food

\section{Introduction}

Supply chain studies have become popular over the last decades both for academia and the professionals. They emphasise the need for a sustainable development in order to incorporate the triple bottom dimensions represented by the social, the environmental and the financial performances in the assessment of the agribusiness activities (Slaper and Hall, 2011). A unified concept of sustainable supply chain management was provided by Hassini et al. (2012). It represents the management of supply chain operations, resources, information and funds in order to maximize the supply chain profitability while at the same time minimizing the environmental impacts and maximizing the social well-being.

By definition, a supply chain comprises all parties involved in fulfilling a customer order (Chopra and Meindl, 2009). Several reviews studies classified researches devoted to the sustainable supply chain management over different criteria. One of the main conclusions was that they focused mainly on the manufacturing sector because it was one of the first industries concerned by environmental regulations (Hassini et al., 2012). In agriculture, such studies mainly discussed the appropriate tools used in the sustainability assessment like simulation modelling in van der Vost et al. (2009) or life cycle assessment in Maton and Hall (2007) based on case studies' assessment (Cox et al., 2007; Hall and Matos, 2010).

For horticulture, it was showed that the supply chains comprise various stakeholders with different perspectives in terms of product quality. Thus, the horticultural chain faces a diverse range of consumer types, characterized by various demands and desires (Schreiner et al., 2013). It is shaped by several specific characteristics (World Bank, 2005): focus on perishables products mainly used for fresh consumption; presents high value added potential in comparison with the traditional farming activities; highly capital intensive industry both in the production and in the post harvesting sectors; market orientated industry, highly controlled by the large internationally operated retail chains; privately owned industry with little governmental interventions; entrepreneurial skills are very important drivers of this business; with several prerequisites for its development like good national and international transport, electricity and communication infrastructure. 
620

The European Union (EU) horticultural market is one of the biggest ones from the world in terms of volume and diversification (World Bank, 2005). The large supermarket chains are the leading actors both in the EU and the United States (Fernandez-Stark et al., 2011). For the vegetable sector it was proved that the total production and profit benefits increase when the transportation costs decrease. Thus both producers and consumers can gain benefits when farms are located close to consumers (Hu et al., 2014). The local markets are important outlets especially for the small horticultural producers (Miyata et al., 2009) that need to find niche or specialized markets in order to survive the increasing international competition (Reardon et al., 2009).

Agritourism can sustain the local products by providing a viable niche for such producers (Flanigan et al., 2015; Mundler and Laughrea, 2016). It is a form of tourism where a countryside entrepreneur valorises the multifunctional dimension of the agribusiness activity and the recreational values of the rural landscape (Phillip et al., 2010). According to Phillip et al. (2010), agritourism can be divided in: 1. generic rural tourism when there is no-working farm activity; 2. 'working farm, passive contact' when the working farm provides the context for tourism, but the relationship between tourism and agriculture goes no deeper than that; 3 . 'Working farm, indirect contact' when it starts to integrate agriculture from the farm with the tourism product; "Working farm, direct contact' when tourists experience agricultural activities in the guesthouses. Agritourism was recognised to have high development possibilities in all New Member States (NMS) after engaging in the post-socialist reforms (Hall, 1998). Over the past years, it developed in Romania both in terms of accommodation offer and as number of tourists (GavrilăPaven, 2015; Vlad et al., 2016) because the rural communities tried to increase their revenues by diversifying to rural tourism (Iorio and Corsale, 2010).

This study has several aims: firstly it will analyse the Romanian supply chain for the fresh horticultural products in terms of sustainable development (vegetables and fruits); secondly, based on this assessment the study will further investigate if agritourism evolved in Romania as a niche market for the local products using a local case-study. These objectives will fill-in at least two gaps identified in the scientific literature: a proper analysis of the Romanian horticulture (vegetables and fruits) marketing chain; what are the main suppliers for food in the agritourism businesses and how this activities support or not local development.

\section{Materials and Methods}

The supply chain analysis of the Romanian vegetables and fruits sectors was based on several qualitative and quantitative statistical data. The official and private data-bases (Eurostat; Romanian National Institute of Statistic - TempoOnline; Romanian National Inspection for Seeds Quality; International Seed Federation etc.) were used to build time series ranging between 1990 and 2015. They cover the most important components of the Romanian supply chain: inputs, production, packing and processing, marketing etc. In order to identify its main trends, statistical research methods like descriptive statistics, exploratory analysis and parametric modelling were used (Chandler and Scott, 2011).
The investigation of the accessibility of the agritourism as a niche market for the local horticultural fresh products was based on a case-study. It used survey research-methods (Fowler, 2009). The case-study was conducted in one of the most important Romanian agritourism destination - Dornelor Depression, Suceava County (Brezuleanu, 2009). The region is located in the North-East Romanian Development region being bounded by the Bistriței Mountains to the South-East, Giumalău Mountain to the North-Est, Calimani Mountains to the South and Suhard Mountains to the North. It has an average altitude of 800 meters, including 10 communes (49 villages) and two urban centres (Vatra Dornei and Broşteni City). The region is recognised for spectacular 'Natura 2000' sites and natural parks that make it attractive for national and international ecotourism.

Individual data was collected by sampling techniques using a probabilistic sample of the guesthouses that operate in the region (Levy and Lemeshow, 2008). The total sample size, for a maximum error limit of 5\% and a probability of $95 \%$, was established to 15 guesthouses. Finally, 16 guesthouses were randomly selected. A standardized questionnaire was used in order to collect internal guesthouse data by face-to-face interviews. The survey comprises a list of well-structured questions divided in four sections. The first section has seven questions that identify the main socio-economic characteristics for the guesthouses' owners. The next section uses seven questions to characterise the touristic offer: type of accommodation; type of additional services etc. There were eight questions about the type of food that was bought from the market, place of acquisition, type of food provided from the household if any, local food bought from the village. Finally there were eleven questions investigating the business' possible future development. The data was processed and analysed using the MS Excel Office.

\section{Results} chain

A synthetic view of the Romanian fruit and vegetables supply

A supply chain has to characterise the main flows of goods developed in order to bring a product to its final consumer. The starting point of any chain analysis is represented by the assessment of the input driven products. Over the past years (1989-2016) the Romanian horticultural input industry has underwent important changes. The vegetables seeds and other planting material markets became largely dominated by imports (Table 1). Internal production has diminished due to high external competition. This concentrated the market similar to the EU and worldwide situation. In 2014, the top 10 seed companies accounted for more than $66 \%$ from the entire global market (EP, 2015). The EU seed market is less concentrated as compared with the worldwide situation but tomato seed input industry presented one of the highest concentrations rates from the EU (EP, 2015). These global seeds players are the main suppliers for the Romanian market, but they have to cope with several internal producers.

One of the main inputs used in agriculture is represented by energy. Its costs accounted for more than $12 \%$ of all intermediate costs of the EU - 28 agricultural sectors in 2012 (Eurostat, 2014a). The Eurostat data showed that oil is the most used fuel in the EU-27 countries, representing around 
Table 1. Romania key data about horticultural seed and other plating material

\begin{tabular}{|c|c|c|c|c|c|c|c|}
\hline \multicolumn{4}{|c|}{ Seed imports (Quantity: million tonnes) } & \multicolumn{4}{|c|}{ Seed imports (Value: USD millions) } \\
\hline Vegetables & Flower & Field & Total & Vegetables & Flower & Field & Total \\
\hline 1571 & 287 & 45854 & 47712 & 21 & 3 & 179 & 203 \\
\hline \multicolumn{4}{|c|}{ Seed exports (Quantity: million tonnes) } & \multicolumn{4}{|c|}{ Seed exports (Value: USD millions) } \\
\hline Vegetables & Flower & Field & Total & Vegetables & Flower & Field & Total \\
\hline 189 & 0 & 137180 & 137369 & 1 & 0 & 331 & 332 \\
\hline \multicolumn{4}{|c|}{ Deficit/Surplus (Quantity: million tonnes) } & \multicolumn{4}{|c|}{ Deficit/Surplus (Value: USD millions) } \\
\hline-1382 & -287 & 91326 & 89657 & -20 & -3 & 152 & 129 \\
\hline \multicolumn{8}{|c|}{ Seed and other planting material (national production) } \\
\hline \multirow{2}{*}{\multicolumn{2}{|c|}{ Horticultural material }} & \multicolumn{3}{|c|}{2005} & \multicolumn{3}{|c|}{2016} \\
\hline & & ha & \multicolumn{2}{|c|}{ Production } & ha & \multicolumn{2}{|r|}{ Production } \\
\hline \multicolumn{2}{|c|}{ Vegetables (seed) } & 391.821 & \multicolumn{2}{|c|}{$883.678(\mathrm{t})$} & 201.138 & \multicolumn{2}{|r|}{$817.55(t)$} \\
\hline \multirow{2}{*}{\multicolumn{2}{|c|}{$\begin{array}{l}\text { Seeds for fruit trees } \\
\text { Grafted fruit trees }\end{array}$}} & 16.428 & \multicolumn{2}{|c|}{$14.2365(\mathrm{t})$} & 23.357 & \multicolumn{2}{|r|}{$27.4932(\mathrm{t})$} \\
\hline & & 58.430 & \multicolumn{2}{|c|}{$1941.224(1000)$} & 0.100 & \multicolumn{2}{|r|}{$14.90000(1000)$} \\
\hline
\end{tabular}

$53 \%$ of the total agriculture's energy consumption in 2010 (Eurostat, 2014b). Horticulture has a high energy demand especially for the indoor production. The European Parliament study from 2015 showed that oil and gas supplying industries are highly concentrated in the entire European Union while energy industry is less concentrated. From the ten top EU electric suppliers, the first five operate also in Romania. The same situation can be founded in the oil and gas industries. Practically, the Romanian horticultural sector has to buy energetic inputs from the big international companies that aligned their marketing and prices strategies to an open European market.

The Romanian fertilisers and plant protection suppliers are also directly connected to the main international producers. These inputs are provided by several big companies that operate at the EU level (European Parliament, 2015). The last year's trend was to use less inorganic fertilisers and more crop protection agents in the entire EU and especially in the Central and Eastern European countries. The main suppliers for farm and irrigation horticultural equipment are also coming from abroad. Practically the industries that supply inputs and technologies for horticultural Romanian producers can be characterised to be highly concentrated in big size international suppliers that are EU or worldwide operators.

The utilised agricultural area (UAA) dedicated to fresh vegetables production has been highly fluctuating in Romania between 1990 and 2015 (Table 2). In the same time, the volume of total production was even more sensitive to the agroenvironmental conditions. Filed-open production became predominant, greenhouses areas diminishing almost 6 times due to the restitutions of the former state companies to the private landowners and the lack of their managerial ability to reduce production costs in an open European market. Fresh fruit production also reduced in terms of UAA and volume.

Farms that operate in the Romanian horticultural sector are concentrated mainly in small size classes in terms of numbers. Thus, in 2013, more than $96 \%$ of farms (specialist horticulture outdoor, indoor or fruit tree) had less than 10 ha in Romania as comparing with only around $85 \%$ in the EU-28 (Table 3). Thus, more than $70 \%$ of Romanian horticultural farms that had less than $2 \mathrm{Ha}$ could be considered to be subsistence and semi-subsistence ones, producing mainly for self-consumption. They use extensive farm family work (expressed in annual working units AWU) and sell only occasionally on the market.

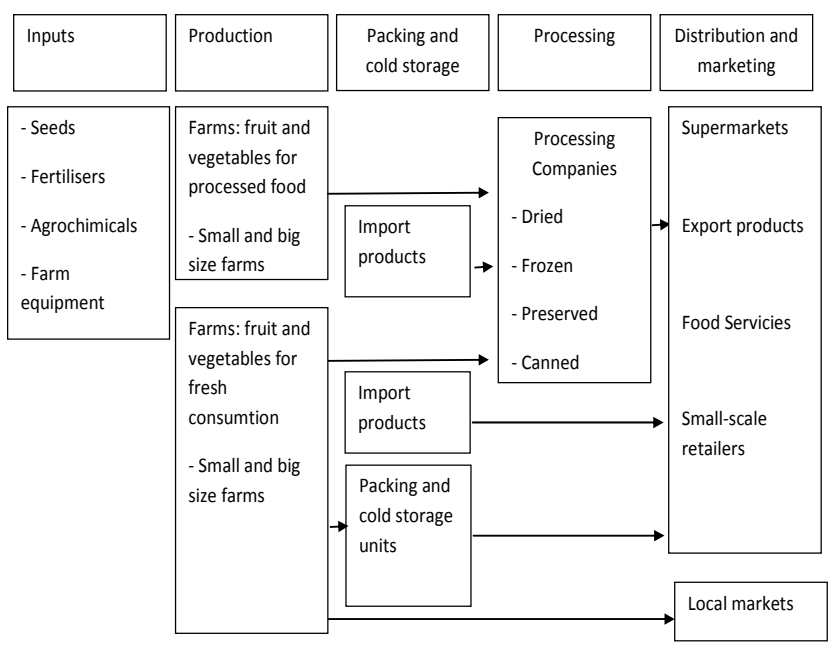

Fig. 1. A schematic view for the Romanian fruit and vegetables marketing chains

The internal production of preserved vegetables and fruits decreased drastically immediately after 1989 (The Netherlands Embassy, 2010). In 2008, there were only 89 processing and canning companies having a total capacity of 237 thousand tons of fruits and vegetables (EVD, 2009). After 2008 the processing capacity increased due to the new investments made from the rural development CAP funds (Table 4).

The internal market is dominated both in volume and value by the large scale supermarkets. The internal producers do not have the capacity to provide packed fruits and vegetables such as to satisfy an internal increasing demand. Thus imports for vegetable products increased almost 8 times between 1991 and 2015 while 3.5 times for fruits (Table 5). Between 1991 and 2015, the commerce balance deficit has severally increased especially for the fresh fruit and vegetables marketing chain. The origin of the imported products was mainly the EU market that accounted for more than $78 \%$ of the total imports.

Agritourism as a potential niche market for the Romanian local horticultural products. Case study - Dornelor Depression

The touristic offer of the Dornelor Depression has increased 3.2 times between 1990 and 2015 (Table 6). It was sustained especially by rural and agritourism investments. Also the number of tourists that arrived in the region increased with $55 \%$. A quarter was interested mainly by the rural areas. 
622

Table 2. Romanian domestic horticultural production 1990-2015 (in ha and tonnes)

\begin{tabular}{|c|c|c|c|c|c|c|c|c|c|}
\hline & $\mathbf{U M}$ & 1990 & 1995 & 2000 & 2005 & 2010 & 2015 & $*(\%)$ & ${ }^{* *}$ \\
\hline \multirow{2}{*}{ Vegetables } & 1000 ha & 216 & 214 & 234 & 267 & 263 & 236 & 2.12 & 22 \\
\hline & $1000 \mathrm{t}$ & 2357 & 2871 & 2528 & 3625 & 3864 & 3630 & 10.75 & 642 \\
\hline Greenhouses & ha & 1843 & 1655 & 1405 & 1127 & 274 & 323 & -20.5 & 1 \\
\hline \multirow{2}{*}{ Fruit tree production } & 1000 ha & 231 & 226 & 207 & 200 & 145 & 139 & $-9,2$ & 40 \\
\hline & $1000 t$ & 1453 & 917 & 1301 & 1647 & 1420 & 1196 & 0.4 & 250 \\
\hline
\end{tabular}

"Average growth rate;"Standard deviation. Source: TempoOnline (2016)

Table 3. Farm structure in the Romanian horticultural production sector 2005-2013 (\% in different size classes)

\begin{tabular}{|c|c|c|c|c|c|c|c|c|c|c|c|c|c|c|c|c|c|}
\hline \multirow{3}{*}{ Farm Type } & \multirow{3}{*}{$\begin{array}{c}\text { Size class } \\
\text { (ha) }\end{array}$} & \multicolumn{4}{|c|}{ Number } & \multicolumn{4}{|c|}{ UAA } & \multicolumn{4}{|c|}{ AWU } & \multicolumn{4}{|c|}{ \% Self consumption } \\
\hline & & \multicolumn{2}{|c|}{2005} & \multicolumn{2}{|c|}{2013} & \multicolumn{2}{|c|}{2005} & \multicolumn{2}{|c|}{2013} & \multicolumn{2}{|c|}{2005} & \multicolumn{2}{|c|}{2013} & \multicolumn{2}{|c|}{2005} & \multicolumn{2}{|c|}{2013} \\
\hline & & $\mathrm{RO}$ & $\mathrm{EU}$ & $\mathrm{RO}$ & EU & $\mathrm{RO}$ & EU & $\mathrm{RO}$ & EU & $\mathrm{RO}$ & EU & $\mathrm{RO}$ & EU & $\mathrm{RO}$ & $\mathrm{EU}$ & $\mathrm{RO}$ & EU \\
\hline \multirow{4}{*}{$\begin{array}{c}\text { Specialist } \\
\text { horticulture } \\
\text { outdoor }\end{array}$} & $0-2$ & 76.0 & 59.6 & 85.6 & 51.8 & 22.1 & 8.0 & 38.7 & 7.8 & 59.6 & 27.8 & 75.2 & 25.4 & 78.6 & 87.2 & 90.4 & 81.1 \\
\hline & $2-9.9$ & 20.3 & 28.3 & 13.7 & 35.0 & 44.7 & 18.9 & 47.3 & 21.8 & 32.2 & 32.0 & 22.6 & 32.3 & 17.9 & 11.3 & 9.8 & 17.8 \\
\hline & $10-50$ & 3.7 & 9.8 & 0.7 & 10.7 & 30.6 & 30.6 & 10.7 & 30.9 & 7.7 & 22.7 & 1.7 & 23.8 & 3.5 & 1.4 & 0.0 & 1.3 \\
\hline & $>50$ & 0.0 & 2.3 & 0.0 & 2.3 & 3.0 & 42.3 & 3.0 & 39.9 & 0.0 & 16.6 & 0.0 & 18.0 & 0.0 & 0.0 & 0.0 & 0.0 \\
\hline \multirow{4}{*}{$\begin{array}{l}\text { Specialist } \\
\text { horticulture } \\
\text { indoor }\end{array}$} & $0-2$ & 68.7 & 67.1 & 84.3 & 61.4 & 19.8 & 17.6 & 35.1 & 12.8 & 52.1 & 45.8 & 73.8 & 37.8 & 68.2 & 76.1 & n.a & n.a \\
\hline & $2-9.9$ & 28.6 & 28.2 & 15.1 & 32.2 & 39.8 & 40.5 & 39.4 & 36.7 & 40.1 & 36.8 & 19.8 & 39.4 & 26.1 & 20.6 & n.a & n.a \\
\hline & $10-50$ & 2.6 & 4.3 & 0.7 & 5.7 & 17.0 & 28.1 & 9.1 & 29.3 & 6.8 & 12.0 & 6.1 & 16.1 & 5.7 & 3.3 & n.a & n.a \\
\hline & $>50$ & 0.1 & 0.3 & 0.1 & 0.6 & 21.9 & 10.9 & 14.9 & 19.0 & 1.0 & 4.3 & 0.3 & 5.8 & 0.0 & 0.0 & n.a & n.a \\
\hline \multirow{4}{*}{$\begin{array}{l}\text { Specialist fruit } \\
\text { tree }\end{array}$} & $0-2$ & 74.7 & 60.9 & 76.6 & 50.4 & 19.4 & 11.3 & 24.6 & 8.0 & 53.1 & 29.0 & 51.4 & 22.7 & 79.1 & 87.6 & 80.9 & 83.0 \\
\hline & $2-9.9$ & 22.6 & 31.4 & 21.6 & 38.8 & 32.1 & 34.5 & 41.2 & 32.5 & 29.5 & 39.8 & 33.5 & 41.4 & 19.4 & 11.4 & 19.1 & 16.2 \\
\hline & $10-50$ & 2.2 & 7.0 & 1.6 & 9.7 & 14.5 & 33.1 & 12.8 & 34.4 & 6.0 & 21.6 & 5.6 & 24.1 & 1.5 & 0.9 & 0.0 & 0.8 \\
\hline & $>50$ & 0.0 & 0.7 & 0.0 & 1.1 & 34.1 & 20.9 & 21.5 & 25.0 & 11.5 & 9.5 & 9.5 & 11.7 & 0.0 & 0.0 & 0.0 & 0.0 \\
\hline
\end{tabular}

n.a Not available. Source: Eurostat (2016)

Table 4. Evolution of the processing industry (2001-2014)

\begin{tabular}{lccccccc}
\hline & 2001 & 2005 & 2008 & 2011 & 2014 & $* *$ \%) \\
\hline Canned vegetables (tons) & 46996 & 67287 & 75840 & 67346 & 70949 & 4.4 \\
Canned fruits(tons) & 2635 & 5358 & 4093 & 3085 & 5595 & 10388.08 \\
\hline
\end{tabular}

*Average growth rate; ${ }^{* *}$ Standard deviation. Source: TempoOnline (2016)

Table 5. Imports/Exports for fresh vegetables and fruits (1991-2015)

\begin{tabular}{|c|c|c|c|c|c|c|}
\hline Imports & 1991 & 1995 & 2000 & 2005 & 2010 & 2015 \\
\hline Total imports 1000 Eur & 4739719 & 7948691 & 14235411 & 32568492 & 46869188 & 62962071 \\
\hline$\% \mathrm{UE}$ & 29 & 50 & 57 & 62 & 72 & 77 \\
\hline Vegetables & 10670 & 12917 & 22248 & 54875 & 149687 & 274705 \\
\hline$\%$ UE & 50 & 14 & 31 & 48 & 62 & 79 \\
\hline Fruits & 29326 & 43585 & 64700 & 136386 & 178660 & 477056 \\
\hline$\% \mathrm{UE}$ & 61 & 25 & 32 & 28 & 60 & 78 \\
\hline Total exports 1000 Eur & 3489858 & 6117452 & 11273261 & 22255071 & 37360259 & 54596057 \\
\hline$\%$ UE & 37 & 54 & 64 & 68 & 72 & 74 \\
\hline Vegetables & 11448 & 20564 & 19855 & 46612 & 65289 & 90256 \\
\hline$\% \mathrm{UE}$ & 67 & 70 & 74 & 97 & 96 & 95 \\
\hline Fruits & 22973 & 19052 & 23308 & 39317 & 61871 & 81883 \\
\hline$\% \mathrm{UE}$ & 77 & 59 & 54 & 59 & 73 & 81 \\
\hline Deficit/ Surplus & 1991 & 1995 & 2000 & 2005 & 2010 & 2015 \\
\hline Total & -36 & -30 & -26 & -46 & -25 & -15 \\
\hline Vegetables & 7 & 37 & -12 & -18 & -129 & -204 \\
\hline Fruits & -28 & -129 & -178 & -247 & -189 & -483 \\
\hline Internal consumption & 1991 & 1995 & 2000 & 2005 & 2010 & 2015 \\
\hline $\begin{array}{l}\text { Fresh and canned vegetables } \\
\text { (kg/person) }\end{array}$ & n.a & n.a & 2.144 & 2.56 & 3.557 & 3.693 \\
\hline $\begin{array}{l}\text { Fresh and canned fruits } \\
\text { (kg/person) }\end{array}$ & n.a & n.a & 7.293 & 6.769 & 7.382 & 7.553 \\
\hline
\end{tabular}

Source: TempoOnline (2016) 
Table 6. Touristic infrastructure and number of tourist in Dornelor Depression (1990-2015)

\begin{tabular}{|c|c|c|c|c|c|c|}
\hline & 1990 & 1995 & 2000 & 2005 & 2010 & 2015 \\
\hline Touristic infrastructure total & 24 & 19 & 33 & 48 & 59 & 79 \\
\hline Rural area (\%) & 13 & 16 & 30 & 23 & 34 & 43 \\
\hline Agritourism (\%) & 0 & 0 & 0 & 48 & 59 & 65 \\
\hline Total tourists in the micro-region & n.a & n.a & 40110 & 48418 & 44555 & 62106 \\
\hline Rural area (\%) & n.a & n.a & 5 & 7 & 15 & 25 \\
\hline Agritourism (\%) & n.a & n.a & 1 & 3 & 14 & 23 \\
\hline
\end{tabular}

Table 7. Main socio-economic characteristics of the guesthouses

\begin{tabular}{|c|c|c|c|c|}
\hline & Type & $\%$ & Type & $\%$ \\
\hline Gender & Masculine & 31 & Feminine & 69 \\
\hline Age & Below 45 & 25 & Above 45 & 75 \\
\hline Education & Primary and highschool & 56 & Bachelor degree & 44 \\
\hline Origin & Urban & 12 & Rural & 88 \\
\hline Household & Yes & 81 & No & 19 \\
\hline
\end{tabular}

Table 8. Source of origin for the main food ingredients used in the guesthouse (2016)

\begin{tabular}{|c|c|c|c|c|c|c|}
\hline \multirow{2}{*}{ Food ingredients } & \multicolumn{2}{|c|}{ Store/ Supermarkets } & \multicolumn{2}{|c|}{ Internal production } & \multicolumn{2}{|c|}{ Local region } \\
\hline & Average & St dev & Average & St dev & Average & St dev \\
\hline Vegetables (fresh and preserved) & 52 & 36 & 31 & 36 & 18 & 23 \\
\hline Fruits (fresh and preserved) & 76 & 32 & 9 & 20 & 14 & 20 \\
\hline Bakery products & 66 & 33 & 29 & 31 & 5 & 12 \\
\hline Milk and milk products & 30 & 37 & 49 & 38 & 21 & 30 \\
\hline Meat and meat products & 53 & 30 & 29 & 29 & 19 & 17 \\
\hline
\end{tabular}

The owners of the guesthouses are mainly female (69\%) and have a good level of education (Table 7). The investigated guesthouses are located mainly in the rural area and share the household premises with the touristic facilities thus promoting a direct contact with agricultural activities.

Food ingredients come mainly from stores and supermarkets with the exception of milk and milk products that are produced mainly in the households (Table 8). The vegetables and fruits (fresh or preserved) are the ones that are bought especially from the open market. The offer of the local products has low shares in the total food basket of the guesthouses.

\section{Discussion}

The EU agriculture supply chain was characterised to favour mainly the supermarkets, the highly intensive farms and the inputs companies in other studies too. Small-size holders are usually excluded from the market (de Fazio, 2016). Shortsupply marketing chains as it was defined in the EU Regulation $1305 / 2013$, represents a way of reaching the sustainability goals by decreasing the transportation burden and consequently the CO2 emissions (Canfora, 2016). Such distribution channels were considered to be a model for the sustainable market developments (Tasca et al., 2017). Based on a local case-study, it was proved that agritourism is only partially valorised as a niche market for the local Romanian products. The horticultural products (vegetables and fruits) are bought mainly from supermarkets. Several explanations already underlined in the literature limit the proper developments of the short-marketing chains. Firstly there is an important lack of financial, human or social rural capital developments (Mikulcak et al., 2015). The organisation of the farming sector is acknowledged as other drawback (Alexandri and Luca, 2014); then, the socio-political uncertainty (Fraser and Stringer, 2009), the lack of entrepreneurial skills or the lack of good governance (cooperation) (Harpa et al., 2016) are other key issues.

\section{Conclusions}

The Romanian supply chain for horticultural products (vegetables and fruits) is largely dominated by imports coming mainly form the EU market. The local producers, mainly subsistence and semi-subsistence ones, do not have the capacity to penetrate the market. For them, the local niche markets are local key survival strategies. Though agritourism has consistently developed over the past years in terms of offer and number of tourists it is only partially used as a local short marketing chain. Further good governance innovations are needed in order to help farmers and touristic infrastructure owners to work together.

\section{References}

Alexandri C, Luca L (2014). Implications of agrarian structures upon the agricultural supply in Romania. ProcediaEconomics and Finance 8:17-24.

Brezuleanu S (2009). Studies regarding the sustainable development of rural tourism and agri-tourism in Vatra Dornei microzone, Suceava County. Cercetări Agronomiceîn Moldova3(139):81-86.

Canfora I (2016). Is the short food supply chain an efficient solution for sustainability in food market? Agriculture and Agricultural Science Procedia 8:402-407.

Chandler R, Scott M (2011). Statistical methods for trend detection and analysis in the environmental sciences. Wiley Publications, USA pp 1-388. 
624

ChopraS, Meindl P (2009). Supply chain management: strategy. planning and operation (4thEd).Prentice-Hall pp 30-120.

Cox A, Chicksand D, Yang T (2007). The proactive alignment of sourcing with marketing and branding strategies: a food service case. Supply Chain Management:An International Journal 12(5):321-333.

de Fazio M (2016). Agriculture and sustainability of the welfare: the role of the short supply chain. Agriculture and Agricultural Science Procedia 8:461466.

EU Regulation (2013). EU Regulation 1305/2013 of the European Parliament and of the Council of 17 December 2013 on support for rural development by the European Agricultural Fund for Rural Development (EAFRD) and repealing Council Regulation (EC) No 1698/2005. EU Official Journal 347/487.

European Parliament (2015). Overview of the agricultural inputs sector in the EU. Directorate-General for Internal Policies. Policy Department B: Structural and Cohesion Policies. Agriculture and Rural Development. Brusselspp 1-128.

EUROSTAT (2014a). Final energy consumption by sector. Retrieved 2016 April 14 from http://ec.europa.eu/eurostat/web/products-datasets//tsdpc320.

EUROSTAT (2014b). Agri-environmental indicator - energy use. Retrieved 2016 April 14 from http://ec.europa.eu/eurostat/statisticsexplained/index.php/Agri-environmental_indicator__energy_use.

EVD (2009). Market survey Romania - Fruits and Vegetables. Business Development Group. Bucharest pp 1-51.

Fernandez-Stark K, Bamber P, Gerefii G (2011). The fruit and vegetables global value chain. Economic Upgrading and Workforce Development. Duke University Center on Globalization. Governance and Competitiveness pp 1-67.

Flanigan S, Blackstock K, Hunter C (2015). Generating public and private benefits through understanding what drives different types of agitourism. Journal of Rural Studies 41:129-141.

Fowler FJ (2009). Survey research methods. SAGE Publications, USA pp 1201.

Fraser E and Stringer L (2009). Explaining agricultural collapse: Macro-forces, micro-crises and the emergence of land use vulnerability in southern Romania. Global Environmental Change 19(1):45-53.

Gavrilă-Paven I (2015). Tourism Opportunities for valorizing the authentic traditional rural space - Study Case: Ampoi and Mures Valleys Microregions. Alba County. Romania. Procedia - Social and Behavioral Sciences 186:111-115.

Hall D (1998). Tourism development and sustainability issues in Central and South-Eastern Europe. Tourism Management 19(5):423-431.

Hall J, Matos S (2010). Incorporating impoverished communities in sustainable supply chains. International Journal of Physical Distribution \& Logistics Management 40(1/2):124147.

Harpa E, Moca S, Rus D (2016). A Comparative Study of Rural Entrepreneurship Romania - Greece. Procedia Technology 22:11001105.

Hassini E, Surti C, Searcy C (2012). A literature review and a case study of sustainable supply chains with a focus on metrics. International Journal of ProductionEconomics 140:69-82.

Hu MC, Chen Y-H,HuangL-C (2014). A sustainable vegetable supply chain using plant factories in Taiwanese markets: A Nash-Cournot model. International Journal of Production Economics 152:49-56.

International Seed Federation (2016). Exports/Imports of seed for sowing by country - Calendar year 2014. Retrieved 2016 April 14 from http://www.worldseed.org/wpcontent/uploads/2016/10/Seed_Export_Overall-2014.pdf.

Iorio M, Corsale A (2010). Rural tourism and livelihood strategies in Romania. Journal of Rural Studies26(2):152-162.

Levy SP, Lemeshow S (2008). Sampling of Populations: Methods and Applications (4thEd). Wiley Publications, USA pp 1-616.

Matos S, Hall J (2007). Integrating sustainable development in the supply chain: The case of life cycle assessment in oil and gas and agricultural biotechnology.Journal ofOperations Management 25(6):1083-1102.

Mikulcak F, Haider J, Abson D, NewigJ, Fischer J (2014). Applying a capitals approach to understand rural development traps: A case study from postsocialist Romania.Land UsePolicy 43:248-258.

Miyata S, Minot N, Hu D (2009). Impact of Contract Farming on Income: linking small farmers, packers. and supermarkets in China. World Development37(11):1781-1790.

Mundler P, Laughrea S (2016). The contributions of short food supply chains to territorial development: A study of three Quebec territories. Journal of Rural Studies 45:218-229.

Phillip S, Hunter C, Blackstock K(2010). A typology for defining agritourism. Tourism Management 31(6):754758.

Reardon T, Barrett C, Berdegue J, Swinnen J (2009). Agrifood industry transformation and small farmers in developing countries. World Development37(11):1717-1727.

Romanian National Inspection for Seeds Quality (2016). Retrieved 2016 April 14 from http://date.incs.bvl.ro/agenti/decmulti_public.aspx.

Romanian National Institute of Statistics (2016). Retrieved 2016 April 14 from TempoOnline.

Schreiner M, Korn M, Stenger M, Holzgreve L, Altmann M (2013). Current understanding and use of quality characteristics of horticulture products. ScientiaHorticulturae 163:63-69.

Slaper T, Hall T (2011). The Triple Bottom Line: What is it and how does it work? Indiana Business Review.Spring2011:48.

Tasca AL, Nessi S, Rigamonti L (2017). Environmental sustainability of agifood supply chains: An LCA comparison between two alternative forms of production and distribution of endive in northern Italy. Journal of Cleaner Production 140(2):725-741.

TheNetherlands Embassy (2010). The Romanian FoodSector and the Use of EU Funds for Investments. Department for Agriculture. Nature and Food Quality. Embassy of the Kingdom of the Netherlands. Bucharest pp 147.

van der Vorst J, Tromp SO, van der Zee DJ (2009). Simulation modelling for food supply chain redesign; integrated decision making on product quality. sustainability and logistics. Int. Journal of Production Research 47(23):6611-6631.

Vlad IM, Toma AD, Stoian E(2016). Exploring the links between the average income and the arrivals' number in tourist accommodation establishments in Romania. Agriculture and Agricultural Science Procedia 10:591-597.

World Bank (2005). The European Horticulture Market: Opportunities for Sub-Saharan African Exporters. WorldBank WorkingPapers 63:1-138. 